Apidologie, 1983, 14 (4), 291-297.

\title{
NOTES ON THE ASCOSPHAERA SPECIES INCITING CHALKBROOD IN HONEY BEES
}

\author{
Martha CHRISTENSEN \\ Department of Botany, University of Wyoming, \\ Laramie, Wroming 82071 \\ Martha GILLIAM \\ U.S. Department of Agriculture, \\ Carl Halden Bee Research Center \\ 2000 E. Allen Road, Tucson, Arizona 85719
}

\section{SUMMARY}

Morphological data and mating studies indicate that Ascosphaera apis is the common incitant of chalkbrood in honey bees, Apis mellifera, in North America. Plus and minus strains of the fungus can be unequally represented in single collections, but an explanation for predominance of one mating type is not readily apparent. Ascosphaera apis and $A$. major differ morphologically and are reproductively isolated.

The publications by SKOU $(1972,1975,1982)$ and SKou and HACKETT (1979) of detailed descriptions of the species in Ascosphaera have allowed us to identify the Nebraska and Wyoming isolates of the chalkbrood fungus (HITCHCOCK and Christensen, 1972) as $A$. apis (Maassen ex Claussen) Olive and Spiltoir. That species and $A$. major (Prökschl and Zobl) Skou can be distinguished by 1) ornamentation of the spore cyst (SKou, 1972; Gochnauer and Hughes, 1976) (uniformly punctate in $A$. apis, irregularly punctate or smooth in $A$. major); 2) ascospore size and length/width ratio $(A$. apis mostly $2.6-3.5 \times 1.4-1.8 \mu \mathrm{m}, 1 / \mathrm{w} 1.9$; A. major 3-4 $\times 1-1.5 \mu \mathrm{m}, 1 / \mathrm{w} 2.6$ ); 3) diameter of the spore cysts (ascocarps) (A. apis up to $120 \mu \mathrm{m}$, mean $80.2 \mu \mathrm{m} ; A$. major up to $250 \mu \mathrm{m}$, mean $128.5 \mu \mathrm{m}$ ); and 4) compatibility in mating tests ( $A$. apis and $A$. major are not interfertile).

Since 1972 we have examined numerous specimens of honey bee larvae killed by chalkbrood to ascertain the species of Ascosphaera present and the mating type(s) 
of hyphae contained in larvae lacking ascocarps (chalky-appearing mummies, THOMAS and LuCE, 1972; BAILEY, 1981). All honey bee larvae submitted to us have been mummified by $A$. apis, and often both mating types were present in single white larvae or in different larvac from the same collection (Table 1). In specimens obtained in 1971-1973 directly or indirectly from Texas, however, the + mating type predominated. The Nebraska colonies containing chalkbrood (Table 1) were " moved from Texas to Nebraska " in May, 1971 (Hitchcock and CHristensen, 1972). Our hypotheses for unequal distribution of + and - mycelia include 1 ) appearance in Texas of a highly vigorous + strain which repressed the - strain during or following germination of ascospores of the - mating type, 2) existence in the Texas and Nebraska infections of conditions within the gut of the larvae which promoted growth of the + strain but inhibited establishment of the - strain, and 3 ) early initial growth of the + strain and its subsequent stimulation of the strain. As an extension from hypothesis 1, genetic differences, if they exist, in the Texas-Nebraska and California-Arizona-Montana strains of $A$. apis could also be

TABL. 1. - Occurrence of + and - mating types of

A. apis in mummies lacking ascocarps (*).

\begin{tabular}{l|c|c|c|c}
\hline \hline \multicolumn{1}{c|}{$\begin{array}{c}\text { Origin of } \\
\text { mumnies }\end{array}$} & $\begin{array}{c}\text { No. of mummies } \\
\text { (and pieces) }\end{array}$ & $\begin{array}{c}\text { No. of mummies } \\
\text { with }+ \text { only }\end{array}$ & $\begin{array}{c}\text { No. of mummies } \\
\text { with - only }\end{array}$ & $\begin{array}{c}\text { No. of mummies } \\
\text { with }+ \text { and }-\end{array}$ \\
\hline Nebraska 1971 & $18(182)$ & 16 & 0 & 2 \\
Texas 1973 & $7(82)$ & 6 & 1 & 0 \\
California 1972 & $18(107)$ & 9 & 7 & 2 \\
Montana 1973 & $6(84)$ & 3 & 3 & 0 \\
Arizona 1974 & $21(126)$ & 1 & 0 & 20 \\
New York 1975 & $4(17)$ & 0 & 0 & 4 \\
Illinois 1976 & $5(10)$ & 1 & 11 & 32 \\
Total & $79(608)$ & 36 & $13.9 \%$ & $40.5 \%$ \\
Percentage & & $45.6 \%$ &
\end{tabular}

(*) Each larva (mummy) was sliced into 2-15 pieces with a sterilized razor blade and after isolation of hyphae from malt agar the pieces were tested separately for mating type. Mummies lacking ascocarps are " chalk " or "white " mummies; those bearing ascocarps are «black " or "salt-and-pepper » mummies. All mummies in the original Nebraska collection were white, whereas $48-89 \%$ of the mummies in the Arizona, California, Montana and Texas collections lacked ascocarps.

explained by their being separate, accidental importations. According to W. Kissinger, who supplied the Montana 1973 mummies (Table 1), chalkbrood in the spring of the year from " across the state » appeared only in bees imported from California and not in " native " colonies overwintered in Montana. The earliest reports of chalkbrood in North American honey bees were from California in 1968-1971 and from Texas-Nebraska in 1971 (HITCHCOCK and CHRISTENSEN, 1972). In successive years in California, the distribution of chalkbrood in honey bees expanded from a single county in 1968 to 3 and 7 counties, respectively, in 1969 and 1970 (Thomas and LuCE, 1972). 
Several observations and comments relative to the above hypotheses seem appropriate here and may stimulate investigation of physiological characteristics of the + and - strains of $A$. apis. There is evidence that the spores of $A$. apis germinate in the gut of the larva and that the larva is susceptible to invasion during a relatively short period, approximately from day 3 through 4 in the 6-day interval prior to pupation (BAILEY, 1981). During that same period, there are dramatic changes in the larva's internal anatomy and mode of nutrition. If conditions within the gut allowing germination and growth of + and -- strains differed, even slightly, the result would be an uneven occurrence of + and - mycelia. Fig. 1 is a schematic illustration of hypothesis 2 . In the Texas and Nebraska infections (Table 1), conditions " A " may have prevailed, whereas in the other infections condition of the gut may have centered on " B " (mummies all + all - or mixed). VANDENBERG and STEPHEN (1982) have evidence that conditions within the gut may influence susceptibility of larvae of the leafcutting bee (Megachile rotundata Fabr.) to invasion by $A$. aggregata. In preliminary tests of the effects on spore germination of filtrates of liquid media that had supported growth of + or mycelia, we were not able to validate hypothesis 3 . On numerous occasions,

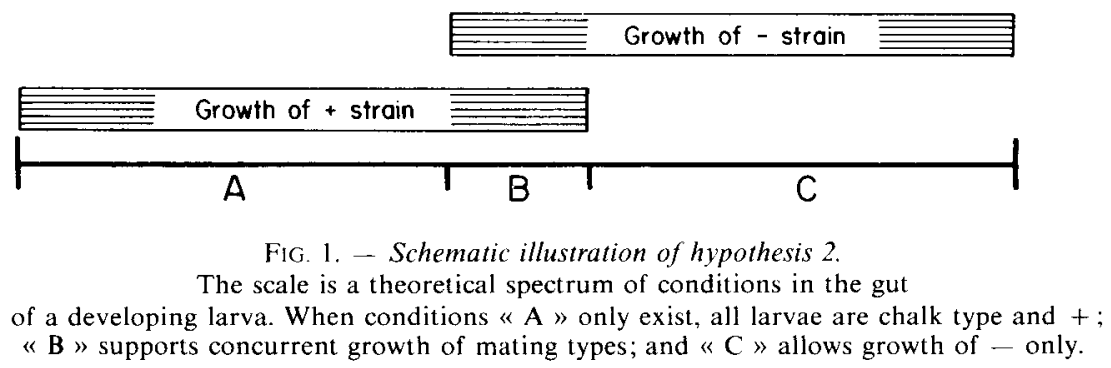

however, we have observed that in mating tests (Fig. 2), --. hyphae commonly invade established + mycelia and form ascocarps "inland " in the + mycelium at up to $3-4 \mathrm{~cm}$ from the interface (observed in 222 of 229 matings). In contrast, + hyphae can invade established - mycelia ( + hyphae could be recovered from established - mycelia 15-70\% of the time), but ascocarp formation occurred in the - mycelium in only 58 of 229 matings. Perhaps, through a mechanism unknown to us, prior growth of the + mycelium is a sequence that has been selected for in the evolution of this fungus. Further development of in vivo techniques (GILLIAM et al., 1978; STEPHEN et al., 1981; VANDENBERG and STEPHEN, 1982) undoubtedly will facilitate investigation of mating-type behavior.

Compatibility among strains was determined using malt agar (RAPER and FENNELL, 1965) and incubation at 30-35 ${ }^{\circ} \mathrm{C}$ in an unmodified atmosphere or in candle jars containing elevated levels of $\mathrm{CO}_{2}$, as recommended by THOMAS and LUCE (1972). In both + and - strains, growth was slightly enhanced in a $\mathrm{CO}_{2}-$ 


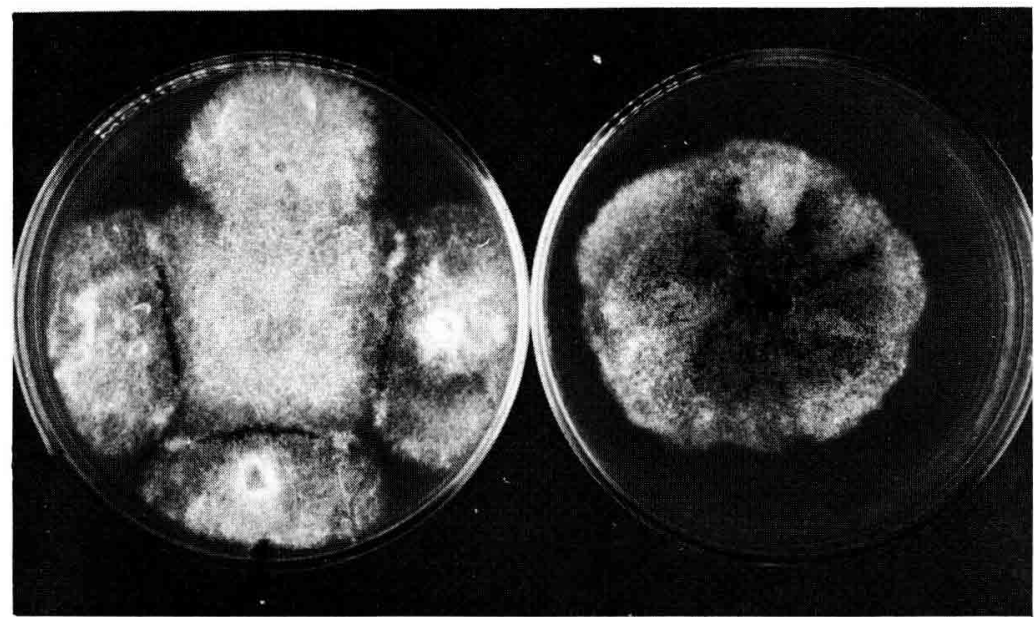

FIG. 2. - Ascosphaera apis in culture, showing one of two plates prepared for determination of mating type left), and a mixed culture, i.e., a culture producing ascocarps (right), grown for separation of + and - strains.

The isolates inoculated centrally in the plates to test mating type were Nebr-1 (+) and Nebr-2l (-) Isolation of marginal hyphae from the culture at right will accomplish segregation of mating types.

augmented atmosphere. Fig. 2 shows a typical test plate for determination of mating type. Nebr-l (+) and Nebr-2l (-) at the centers of the Petri plates were grown at 30-35 oC for 24-26 hours; 4-5 unknown strains were then inoculated peripherally, and after an additional 3-5 days, mating type of the test cultures was indicated by presence of ascocarps at the colony interfaces. Mating type of the two Nebraska strains was assigned on the basis of fruiting in matches with A.T.C.C. 13785, L. S. Olive's A. apis female strain (SPILtolr and Olive, 1955).

In cultures obtained as " mixed " cultures, separation of + and - hyphae was achieved by hyphal-tip isolations from colonies on malt agar or a honey-peptone medium with $1 \mathrm{~g}$ peptone/1 (Fig. 2). In two early experiments, - hyphae commonly were peripheral on media with peptone at $0.1 \mathrm{~g} / 1$ or less, and + hyphae were most often peripheral on media with peptone at $10.100 \mathrm{~g} / 1$. In later trials, use of a single medium and examination of $8-10$ hyphal-tip isolates invariably provided separate cultures of the constituent strains.

On the basis of morphological data and mating studies, we have determined that the following European and North American strains are morphologically identical, interfertile, and thus conspecific : 1) "Bailey's A. apis", a culture obtained from a portion of herbarium material (LB-1) collected at Rothamsted Experiment Station in England in 1974 and sent to us by Dr. BAILEY, 2) Olive and SPILtOIR's A. apis 
(A.T.C.C. 13785 and N.R.R.L. 629, a mixed culture), 3) « Mexican A. apis », a mixed culture derived from mummies collected in Mérida, Mexico in 1981, and 4) various isolates obtained from the U.S. and Canada (H.B.C.-1, from mummies in collection D.A.O.M. 134568, British Columbia 1971, supplied by S. J. Hughes; Tuc-6 and Tuc-7 from Arizona in 1974; Nebr-1, Nebr-21 and others from Nebraska in 1971; Ith-2 from New York in 1975; Ki-2 from Illinois in 1976; and many isolates from California 1972, Montana 1973 and Texas 1973). All of the above-listed cultures formed ascocarps with the A. apis from Nebraska. In contrast, Ascosphaera major (C.B.S.686.71) did not form ascocarps with any of the strains tested. Our mating results confirm the reports by MAURIzIo (1935) and PRöKSCHL (1953) of sexual incompatibility between the "major" and " minor " forms of the chalkbrood fungus.

There are now 7 species in the genus Ascosphaera (SKOU, 1972, 1975, 1982; RosE et al., 1984). Ascosphaera apis is the primary incitant of chalkbrood in honey bees, Apis mellifera, in Europe and in North America (BAILEY, 1981; Rose et al., 1984). Ascosphaera major and A. proliperda Skou reportedly incite chalkbrood in honey bees and leafcutting bees (Megachile centuncularis L.) and in leafcutting bees only, respectively (SKou, 1972). BaILey (1981) contends that $A$. major may be primarily a saprophyte that can secondarily invade moribund larvae. At present there are no autpentic records for either $A$. major or $A$. proliperda from North America and both appear to be infrequent elsewhere in the world (BAILEY, 1981; STEPHEN et al., 1981). Ascosphaera aggregata Skou incites chalkbrood in various megachilids and other wild bees and has had devastating effects on populations of Megachile rotundara in the United States in Washington, Oregon, Utah, Nevada and Idaho (STEPHEN et al., 1981). Megachile rotundata has been intensively managed for pollination of seed crops in those states since the 1960's; it was accidently introduced to the east coast of the U.S. in the 1930's. Three Ascosphaera species, A. atra SKoU and HAcketT, $A$. fimicola Skou, and $A$. asterophora Skou, like Bettsia alvei (BETTS) SKou, appear to be solely or primarily saprophytic (SKoU, 1975, 1982; SKOU and НАСКЕTT, 1979).

A key to described species in Ascosphaera and accounts of morphological variation, reproductive isolation, host specificity, and occurrence in North America is available elsewhere (Rose et al., 1984). We fully expect that an understanding of the morphological differences among species in Ascosphaera, together with delimitation of host specificities, species distributions, and especially factors affecting pathogenicity, will aid progress toward reduction in economic losses to both honey producers and seed growers. Already it can be postulated that in A. apis the characteristic delay in anastomosis between + and - mycelia will make chalkbrood in honey bees more susceptible to control than chalkbrood ( $A$. aggregata) in leafcutting bees, where there is evidence that anastomosis may occur between germinating ascospores (KISH, 1980). 


\title{
ACKNOWLEDGEMENTS
}

We thank L. Bailey, D. Dejong, G. M. Gonzales, J. D. Hitchcock, S. J. Hughes, E. E. Killion, W. A. Kissinger, Leo Vanderpool, and the Centraalbureau voor Schimmelcultures (C.B.S.) for supplying bee mummies and cultures of Ascosphaera species.

Received for publication in June 1983.

\author{
RÉSUMÉ \\ NOTES SUR L'ESPÈCE D'ASCOSPHAERA QUI INDUIT \\ LE COUVAIN PLÂTRÉ CHEZ LES ABEILLES
}

On a examiné de nombreuses larves momifiées tuées par le couvain plâtré et provenant de diverses régions afin de déterminer l'espèce d'Ascosphaera présente et les types de reproduction sexuée des hyphes contenues dans des momies, qui apparaissent plâtrées et sont dépourvues d'ascocarpes. Toutes les larves d'abeilles ont été momifiées par Ascosphaera apis, ainsi que le montrent les études morphologiques de l'ornementation de l'ascocarpe et la comptabilité des tests de reproduction sexuée.

La comptabilité parmi les souches a été déterminée en testant des souches inconnues $(+)$ et $(-)$ avec une souche femelle d'A. apis de L. S. Olive sur de l'agar malté dans des boîtes de Pétri avec incubation sous $\mathrm{CO}_{2}$

Le type de reproduction sexuée a été fixé d'après la formation de l'ascocarpe. On a séparé des cultures contenant à la fois des souches $(+)$ et $(-)$ en isolant des extrémités d'hyphes à partir de colonies de champignons.

Les deux types de reproduction sexuée $(+)$ et $(-)$ sont souvent présents dans une même larve blanche ou dans des larves de la même collection. Ils sont également souvent représentés inégalement dans une même collection et le type $(+)$ prédomine. Les résultats montrent que les hyphes $(-)$ envahissent habituellement les myceliums $(+)$ formés et y développement des ascocarpes. Cela s'est produit dans 222 des 229 reproductions sexuées. Au contraire des hyphes $(+)$ peuvent envahir des myceliums $(-)$ mais la formation d'ascocarpes dans le mycelium $(-)$ ne s'est produite que dans 58 cas de reproduction sexuée sur 229. Ainsi la croissance préalable du mycelium (+) peut être une séquence qui a été sélectionnée dans l'évolution de ce champignon.

A. apis et A. major diffèrent du point de vue morphologique et sont isolés sur le plan reproductif. A l'heure actuelle il n'existe pas de document authentique sur la présence d'A. major en Amérique du Nord.

\section{ZUSAMMENFASSUNG}

\section{UNTERSUCHUNGEN AN ASCOSPHAERA ARTEN, DIE KALKBRUT} BEI DER HONIGBIENE VERUSACHEN

Zahilreiche mumifizierte, durch Kalkbrut getötete Larven von verschiedenen geographischen Gebieten wurden untersucht, um die Ascosphaera-Art und den Paarungstyp der Hyphen aus kalkig aussehenden Mumien ohne Ascocarpen zu bestimmen. Alle Honigbienenlarven wurden von Ascosphaera apis mumifiziert, wie aus morphologischen Studien des Ascocarpus-Ornaments, der Ascosporengrösse und deren Längen-Breiten-Verhältnis, dem Durchmesser des Ascocarpus und der Kompatibilität bei Paarungsversuchen hervorging.

Die Kompatibilität der Linien wurde getestet, indem unbekannte (+) und (-) Linien gegen L.S. Olive's A. apis Weibchen Linie auf Malz-Agar in Petrischalen aufgetragen wurden und unter $\mathrm{CO}_{2}$ 
inkubiert wurden. Der Paarungstyp wurde auf der Basis von Ascocarpus-Bildungen bestimmt. Kulturen, die $(+)$ und $(-)$ Linien enthielten, wurden durch Isolation von Hyphen-Spitzen aus den Pilzkolonien getrennt.

Oft kamen (+) und (-) Paarungstypen in einer einzelnen weißen Larve oder in verschiedenen Larven derselben Probe vor. Außerdem waren die $(+)$ und $(-)$ Paarungstypen in den einzelnen Proben oft ungleich häufig, der $(+)$ Typ dominierte. Die Ergebnisse von Paarungstests zeigten, daß meist die (-) Hyphen in das bestehende $(+)$ Myzel eindringen und dann Ascocarpen im $(+)$ Myzel gebildet werden. Dies wurde in 222 von 229 Paarungen beobachtet. Der umgekehrte Fall $-(+)$ Hyphen dringen in (-) Myzel ein - wurde auch beobachtet, die Bildung von Ascocarpen im (-) Myzel trat jedoch nur in 58 von 229 Paarungen auf. Man kann daraus schließen, daß ein bevorzugtes Wachstum von $(+)$ Myzel während der Evolution dieses Pilzes herausselektioniert wurde.

Ascosphaera apis und A. major unterscheiden sich morphologisch und sind sexuell isoliert. Gegenwärtig gibt es keine zuverlässigen Daten über $A$. major in Nordamerika.

\section{LITERATURE CITED}

BAILEY L., 1981. - Honey bee pathology. Academic Press, New York.

Gilliam M., Taber S., Rose J. B., 1978. - Chalkbrood disease of honey bees, Apis mellifera L. : a progress report. Apidologie, 9, 75-89.

Gochnauer T. A., Hughes S. J., 1976. - Detection of Ascosphaera apis in honey bee larvae (Hymenoptera : Apidae) from eastern Canada. Canad Entomol., 108, 985-988.

Hitchcock J. D., Christensen M., 1972. - Occurrence of chalkbrood (Ascosphaera apis) in honey bees in the United States. Mycologia, 64, 1193-1198.

KisH L. P., 1980. - Spore germination of Ascophaera spp. associated with the alfalfa leafcutting bee, Megachile rotundata. J. Invertebr. Pathol, 36, 125-128.

MaurizıO A., 1935. - Beiträge zur Kenntnis der Pilzflora im Bienenstock. I. Die Pericystis-Infektion der Bienenlarven. Ber. Schweiz. Bot. Ges., 44, 133-156.

Prokschl H., 1953. - Beiträge zur Kenntnis der Entwicklungsgeschichte von Pericystis apis Maassen. Arch. Mikrobiol., 18, 198-209.

Raper K. B., Fennell. D. I., 1965. - The genus Aspergillus. Williams and Wilkins, Baltimore.

Rose J.B., Christensen M., Wilson W. T., 1984. - Ascosphaera species inciting chalkbrood in North America and a taxonomic key. Mycotaxon, 19,41-55.

Sкоu J. P., 1972. - Ascosphaerales. Friesia, 10, 1-24.

Skou J. P., 1975. - Two new species of Ascosphaera and notes on the conidial state of Bettsia alvei. Friesia, 11, 62-74.

Skou J. P., 1982. - Ascosphaera asterophora species nova. Mycotaxon, 14, 149-159.

Skou J. P., Hackett K., 1979. - A new homothallic species of Ascosphaera. Friesia, 11, 265-271.

Spiltoir C. F., Olive L. S., 1955. - A reclassification of the genus Pericystis Betts. Mycologia, 47, 238-244.

Stephen W. P., Vandenberg J. D., Fichter B. L., 1981. - Ethiology and epizootiology of chalkbrood in the leafcutting bee, Megachile rotundata (Fabricius), with notes on Ascosphaera species. Station Bull. 653, Agric. Exp. Sta., Oregon State Univ, Corvallis.

Thomas G. M., Luce A., 1972. - An epizootic of chalkbrood, Ascosphaera apis (Massen [sic] ex Claussen) Olive and Spiltoir in the honey bee, Apis mellifera L. in California. Amer. Bee J., 112, 88-90.

VANDenberg J. D., Stephen W. P., 1982. - Etiology and symptomatology of chalkbrood in the alfalfa leafcutting bee, Megachile rotundata. J. Invertebr. Pathol., 39, 133-137. 